\title{
Determining Vocational High School of Health Students' Attitudes Toward Physical Education and Sports Class and Their Self-Efficacy
}

\author{
Murat SARIKABAK \\ Bartın University, Faculty of Sport Sciences, Bartın, TURKEY
}

Email: msarikabak@bartin.edu.tr

Type: Research Article (Received: 10.08.2019 -Corrected: ----

- Accepted: 24.09.2019)

\begin{abstract}
The purpose of the present study was to determine the attitudes of vocational high school of health students toward physical education and sports class and their self-efficacy. The population of the study was comprised of 245 students (174 female, 71 male) who studied at a state vocational high school of health in İmit, Kocaeli province and they were selected via convenience sampling method. The data were collected through "personal information form," "attitude toward physical education and sports scale," and "academic self-efficacy scale." Then, these data were analyzed through SPSS 21 package program parametric tests, after they were checked for normality and normal distribution. In analysis of the data, descriptive data, t-test, one-way variance analysis (ANOVA) and pearson correlation analysis were used. The findings revealed that although the rate of participating in school sports was high in the students, (n: 137) the rate of participating in licensed sports was low (n: 26). While the students' attitude scores toward physical education and sports class were above average ( :124.26) they did not differ according to gender and age ( $p>0.05)$. However, the students' attitude scores toward physical education and sports class did differ significantly $(p<0.05)$ in support of the ones who participate in school sports (n: 137) and licensed sports (n:26). When the students' academic self-efficacies were compared according to gender variance, the results differed significantly in support of the female students $(\mathrm{p}<0.05)$. On the other hand, there was no a significant difference between academic self-efficacy and age group; and school sports participation rate and licensed sports participation rate $(\mathrm{p}>0.05)$. Finally, pearson correlation analysis revealed that there was no a significant relationship between the students' attitudes toward physical education and sports class and academic self-efficacy ( $p>0.05)$. The results were discussed in the light of related literature and a few suggestions were made in order to contribute in the field.
\end{abstract}

Keywords: Vocational High School of Health, Attitude toward Physical Education and Sports Class, Academic Self-efficacy 


\section{Introduction}

It is well-known that health service workers have an important part among the occupations which are considered to be pioneers regarding human health. This field consists of several important workers such as doctors, technicians, nurses and chemists. The present study aims to examine vocational high school of health students who are expected to obtain a crucial and effective role in the health sector, physical education and sports class whose health benefits are agreed upon and the students' attitudes toward the class and academic self-efficacy; then bring these three titles together and examine their relationship with certain personal traits.

The students are able to work at private or state health institutes after graduating from these high schools and their attitudes toward physical education and sports class are expected to affect their work and social lives. Today's scientists agree on the fact that physical activity which is done at certain frequency and correct intensity can benefit an individual's physical and spiritual health. The effects indicate quite a wide area such as socialization of the disabled, normalizing the anxiety of children at the development stage, social health and supporting psychomotor development (Janssen an LeBlanc, 2010; Strong et al., 2005; PAGA Committee, 2008; Karakaş and Yaman, 2014; Macgregor, Borghese and Janssen, 2019).

Pupilage is pivotal in maintaining behaviors. Health sector workers' awareness and application of health benefits of physical activity since pupilage can be regarded as a job requirement. Observing physical education and sports classes in vocational high schools of health where there are several theoretical and applied classes through studies will contribute in creating terminal behavior plans.

Friends, parents and teachers who act as social agents in high school period can create an effective physical activity environment through sports activities (Akcan and Bulgu, 2012). Sports activities are the process in which enjoyable sports applications transform into permanent behavior.

Academic motivation, discipline and self-efficacy are of great importance especially in occupations which are likely to influence human life. Self-efficacy has begun to be included as an important concept following Bandura's (1977) contributions in the field of education, based on social learning theory. Whereas this concept is presented as the ability to organize oneself and display positive behavior, it is evidently high in creating effective strategies and coping. The results of a study which reveal the effects of academic self-efficacy on satisfaction with life are remarkable (Akbay 2009; Aktaş, 2017; Bandura, 1977; Eggen and Kauchak, 1999; Kim and Hong, 2019). This can be defined as one's belief in succeeding (Zimmermann, 1995). Through an optimistic perspective, it is possible to develop and transmit this belief through education (Schunk, 2009). A research which studies the relationship between academic self-efficacy and health sector assesses a number of psychometric data and emphasizes the importance of academic self-efficacy (Zhang et al., 2018).

Increasing the attitude toward physical education and sports class, high academic selfefficacy and vocational high school of health students working with these outcomes can provide individuals with social gains. A physically and spiritually fit health worker's developing performance, socially being an example, constant academic efforts and influence 
on social health are possible through developing attitude toward physical education and sports class which heightens academic self-efficacy and physical activity. In the light of the information above, the present study aims to determine vocational high school of health students' attitudes toward physical education and sports class and their academic selfefficacy.

\section{Methodology}

\section{Model of the Study}

The study was conducted via the "survey method." The survey method is "an approach which aims to display a situation that existed or still exists as it is" (Karasar, 2016: 109).

\section{Population and Sample of the Study}

The population of the study was comprised of vocational high school of health students who studied in Kocaeli, İzmit; and the sample consisted of 245 high school students (174 female, 71 male) who were selected via random sampling method.

\section{Data Collection}

Before data collection, necessary permissions were received from related institutions to conduct the study. Then, the researcher explained the purpose of the study with the help of the school's guidance teacher and collected the data from volunteer students.

\section{Data Collection Tools}

The data were gathered through "personal information form," "attitude toward physical education and sports scale," and "academic self-efficacy scale."

\section{Personal Information Form}

The students were given a 4-question "Personal Information Form" in order to determine their certain demographic information. The form contained questions regarding the students'; gender, age, whether they participated in licensed sports and whether they participated in school sports.

\section{Physical Education and Sports Attitude Scale}

The study used "Physical Education and Sports Class Attitude Scale" which was developed by Güllü and Güçlü (2009). The scale included one dimension and its variance value was $36.19 \%$; while primary value was 12,67 . Cronbach's Alpha reliability index of the scale was found as .94. The scale was a 5-point Likert scale and its rating was as follows: "Completely agree (5), Agree (4), Unsure (3), Disagree (2), and Completely Disagree (1). The scale included 11 negative (items 3,17,19,20,24,25,26,29,30,34 and 35) and 24 positive items, 35 items in total. The lowest score one can get from the scale was 35, while the highest score was 175 (Güllü and Güçlü, 2009). Cronbach's Alpha index regarding the present study's instrument was found to be 90 . 


\section{Academic Self-Efficacy}

The study also used "Academic Self-efficacy Scale" which was developed by Jerusalem and Schwarzer (1981) and adapted into Turkish by Y1lmaz, Gürçay and Ekici (2007). The scale included 7 items. The items were 4-point Likert style and read: 1- Not true, 2-Nearly true, 3True, 4- Exactly true (Yılmaz, Gürçay and Ekici, 2007). The scale's validity and reliability for high school students were calculated by Aksu (2015). Study conducted by Aksu found that the scale was one-dimensional, explained one factor and its variance value was $51.7 \%$. Besides, the Cronbach's Alpha index of the scale was .80. Cronbach's Alpha index of the scale for the present study was found as .64.

\section{Data analysis}

Data gathered from the students were checked one by one in case of possible coding mistakes. After omitting wrong, missing or carelessly coded data, the remaining ones were coded and transmitted into SPSS program. Normality test was conducted before analyzing the data and the test showed the data were suitable for normal distribution. Therefore, parametric tests were chosen to evaluate the data. In general analysis, descriptive statistics, t-test, oneway variance analysis (ANOVA) and pearson correlation analysis were used.

\section{Results}

This section of the paper presents findings gathered from the analyses.

Table 1. Frequency and percentage distribution of the students' demographic information

\begin{tabular}{|c|c|c|}
\hline Gender & $\mathbf{n}$ & \% \\
\hline Female & 174 & 71,00 \\
\hline Male & 71 & 29,00 \\
\hline Age & $\mathbf{n}$ & \% \\
\hline 14 & 26 & 10,6 \\
\hline 15 & 145 & 59,2 \\
\hline 16 & 59 & 24,1 \\
\hline 17 & 15 & 6,1 \\
\hline Participating in school sports & $\mathbf{n}$ & $\mathbf{\%}$ \\
\hline Yes & 137 & 55,9 \\
\hline No & 108 & 44,1 \\
\hline Participating in licensed sports & $\mathbf{n}$ & $\mathbf{\%}$ \\
\hline Yes & 26 & 10,6 \\
\hline No & 219 & 89,4 \\
\hline
\end{tabular}

Table 1 shows that 174 of the students were female $(71 \%)$; while 71 of them were male (29\%). 26 of them were 14 years old (10.6\%); while 145 of them $15(59.2 \%) ; 59(24.1 \%)$ of them 16; and $15(6.1 \%)$ of them are 17 years old. 137 of the students $(55.9 \%)$ participated in 
school sports, while 108 of them $(44.1 \%)$ did not participate in school sports. Regarding licensed sports, the table shows that 26 of the students (10.6\%) participated in licensed sports, while 219 of them (89.4\%) did not participate in licensed sports.

Table 2. Descriptive Statistic Results of the Students' attitude toward Physical Education and Sports Class and Academic Self-efficacy Score Means

\begin{tabular}{|c|c|c|c|}
\hline & $\mathrm{n}$ & $\overline{\mathrm{X}}$ & $\mathrm{SS}$ \\
\hline $\begin{array}{c}\text { Attitude toward } \\
\text { Physical Education and } \\
\text { Sports Class }\end{array}$ & 245 & 124,26 & 27,79 \\
\hline Academic Self-efficacy & 245 & 17,00 & 3,53 \\
\hline
\end{tabular}

Table 2 shows the descriptive statistic results of the students' attitude scores toward physical education and sports class and academic self-efficacy scores. Mean score of the students' attitude toward physical education and sports class was 124.16; while the mean score of their academic self-efficacy was 17.00 .

Table 3. T-test Results of the Students' Attitude toward Physical Education and Sports Class Scores according to Gender

\begin{tabular}{|c|c|c|c|c|c|c|}
\hline & Gender & $\mathrm{n}$ & $\overline{\mathrm{X}}$ & $\mathrm{SS}$ & $\mathrm{t}$ & $\mathrm{p}$ \\
\hline $\begin{array}{c}\text { Attitude toward Physical } \\
\text { Education and Sports } \\
\text { Class }\end{array}$ & Female & 174 & 125,20 & 25,93 & & \multirow{2}{*}{, 75} \\
\cline { 2 - 5 } & Male & 71 & 121,98 & 32,00 &, 45 \\
\hline
\end{tabular}

Table 3 presents the t-test results of the students' attitude toward physical education and sports class scores compared according to gender. The results show that the students' attitude toward physical education and sports class scores did not differ significantly according to their gender ( $\mathrm{p}>.05)$.

Table 4. One-way Variance Analysis Results of the Students' Attitude toward Physical Education and Sports Class Scores according to Age Groups

\begin{tabular}{|c|c|c|c|c|c|c|}
\hline \multicolumn{2}{|c|}{} & $\mathrm{n}$ & $\overline{\mathrm{X}}$ & $\mathrm{SS}$ & \multirow{2}{*}{$\mathrm{F}$} & $\mathrm{p}$ \\
\hline \multirow{2}{*}{$\begin{array}{c}\text { Attitude toward } \\
\text { Physical Education } \\
\text { and Sports Class }\end{array}$} & 14 & 26 & 120,92 & 31,27 & & \\
\cline { 2 - 6 } & 15 & 145 & 126,58 & 27,39 & \multirow{3}{*}{1,15} & \multirow{2}{*}{, 32} \\
\cline { 2 - 6 } & 16 & 59 & 119,28 & 27,31 & & \\
\hline
\end{tabular}


Table 4 presents the results for the one-way variance analysis (ANOVA) which was used to analyze the students' attitude toward physical education and sports class scores according to their age group. The results show that the students' attitude toward physical education and sports scores did not significantly differ according to their age group ( $\mathrm{p}>.05)$.

Table 5. T-test Results of the Students' Attitude toward Physical Education and Sports Class Scores according to Participating in School Sports

\begin{tabular}{|c|c|c|c|c|c|c|}
\hline & $\begin{array}{c}\text { Participating in } \\
\text { School Sports }\end{array}$ & $\mathrm{n}$ & $\overline{\mathrm{X}}$ & $\mathrm{SS}$ & $\mathrm{t}$ & $\mathrm{p}$ \\
\hline $\begin{array}{c}\text { Attitude toward } \\
\text { Physical Education } \\
\text { and Sports Class }\end{array}$ & Yes & 137 & 129,72 & 29,54 & \multirow{2}{*}{, 00} \\
\cline { 2 - 5 } & No & 108 & 117,34 & 23,78 & 3,54 &, 00 \\
\hline
\end{tabular}

Table 5 shows the results for the t-test which was used to analyze the students' attitude toward physical education and sports class scores according to participating in school sports. The results revealed that the students' attitude toward physical education and sports class scores differed according to whether or not they participated in school sports $(\mathrm{p}<.05)$.

Table 6. T-test Results of the Students' Attitude toward Physical Education and Sports Class according to Participating in Licensed Sports

\begin{tabular}{|c|c|c|c|c|c|c|}
\hline & $\begin{array}{c}\text { Participating } \\
\text { in Licensed } \\
\text { Sports }\end{array}$ & $\mathrm{n}$ & $\overline{\mathrm{X}}$ & $\mathrm{SS}$ & $\mathrm{t}$ & $\mathrm{p}$ \\
\hline $\begin{array}{c}\text { Attitude toward } \\
\text { Physical Education } \\
\text { and Sports Class }\end{array}$ & Yes & 26 & 134,76 & 25,58 & \multirow{2}{*}{2,05} &, 04 \\
\cline { 2 - 7 } & No & 219 & 123,02 & 27,84 & \\
\hline
\end{tabular}

Table 6 shows the results for t-test which was used to analyze the students' attitude toward physical education and sports class scores according to whether or not they participate in licensed sports. The results revealed that the attitude scores of the students toward physical education and sports class did differ according to whether or not they participated in licensed sports $(\mathrm{p}<.05)$.

Table 7. T-test Results of the Students' Academic Self-efficacy Scores according to their Gender

\begin{tabular}{|c|c|c|c|c|c|c|}
\hline & Gender & $\mathrm{n}$ & $\overline{\mathrm{X}}$ & $\mathrm{SS}$ & $\mathrm{t}$ & $\mathrm{p}$ \\
\hline \multirow{2}{*}{$\begin{array}{c}\text { Academic Self- } \\
\text { efficacy }\end{array}$} & Female & 174 & 17,40 & 3,54 & \multirow{2}{*}{2,79} & \multirow{2}{*}{, 00} \\
\cline { 2 - 5 } & Male & 71 & 16,02 & 3,34 & \\
\hline
\end{tabular}


Table 7 shows the results for the t-test which was used to analyze the students' academic selfefficacy scores according to their gender. The results revealed that academic self-efficacy scores differed according to gender $(\mathrm{p}<.05)$.

Table 8. One-way Variance Analysis Results of the Students' Academic Self-efficacy Scores according to their Age Group

\begin{tabular}{|c|c|c|c|c|c|c|}
\hline \multicolumn{2}{|c|}{} & $\mathrm{n}$ & $\overline{\mathrm{X}}$ & $\mathrm{SS}$ & \multirow{2}{*}{$\mathrm{F}$} & $\mathrm{p}$ \\
\hline \multirow{3}{*}{$\begin{array}{c}\text { Academic Self- } \\
\text { Efficacy }\end{array}$} & 14 & 26 & 17,23 & 3,55 & & \\
\cline { 2 - 6 } & 15 & 145 & 17,31 & 3,55 & \multirow{3}{*}{1,69} & \multirow{2}{*}{, 17} \\
\cline { 2 - 6 } & 16 & 59 & 16,54 & 3,44 & & \\
\cline { 2 - 6 } & 17 & 15 & 15,46 & 3,46 & & \\
\hline
\end{tabular}

Table 8 shows the results for one-way variance analysis (ANOVA) which was used to compare the students' academic self-efficacy scores according to their age group. The results revealed that academic self-efficacy scores of the students did not differ according to their age group $(\mathrm{p}>.05)$.

Table 9. T-test Results of the Students' Academic Self-efficacy Scores according to Participating in School Sports

\begin{tabular}{|c|c|c|c|c|c|c|}
\hline & $\begin{array}{c}\text { Participating in } \\
\text { School Sports }\end{array}$ & $\mathrm{N}$ & $\overline{\mathrm{X}}$ & $\mathrm{SS}$ & $\mathrm{t}$ & $\mathrm{p}$ \\
\hline $\begin{array}{c}\text { Academic Self- } \\
\text { Efficacy }\end{array}$ & Yes & 137 & 16,80 & 3,45 & \multirow{2}{*}{$-1,00$} & \multirow{2}{*}{, 31} \\
\cline { 2 - 5 } & No & 108 & 17,25 & 3,64 & \\
\hline
\end{tabular}

Table 9 presents the results for the t-test which was used to compare the students' academic self-efficacy scores according to participating in school sports. The results revealed that academic self-efficacy scores did not differ according to participating in school sports $(\mathrm{p}>.05)$.

Table 10. T-test Results of the Students' Academic Self-Efficacy Scores According to Participating in Licensed Sports

\begin{tabular}{|c|c|c|c|c|c|c|}
\hline & $\begin{array}{c}\text { Participating } \\
\text { in Licensed } \\
\text { Sports }\end{array}$ & $\mathrm{n}$ & $\overline{\mathrm{X}}$ & $\mathrm{SS}$ & $\mathrm{t}$ & $\mathrm{p}$ \\
\hline $\begin{array}{c}\text { Academic Self- } \\
\text { efficacy }\end{array}$ & Yes & 26 & 17,57 & 3,41 & \multirow{2}{*}{, 87} & \multirow{2}{*}{, 38} \\
\cline { 2 - 7 } & No & 219 & 16,93 & 3,55 & \\
\hline
\end{tabular}


Table 10 presents the results for the t-test which was used to compare the students' academic self-efficacy scores according to participating in licensed sports. The results revealed that the academic self-efficacy scores did not differ according to participating in licensed sports (p>.05).

Table 11. Results for the Relationship between the Students' Attitude toward Physical Education and Sports Class Scores and Academic Self-efficacy Scores

\begin{tabular}{|c|c|c|}
\hline \multicolumn{2}{|c|}{} & $\begin{array}{c}\text { Academic } \\
\text { Self-efficacy }\end{array}$ \\
\hline $\begin{array}{c}\text { Attitude toward } \\
\text { Physical Education } \\
\text { and Sports Class }\end{array}$ & $\mathrm{r}$ &, 066 \\
\cline { 2 - 3 } & $\mathrm{p}$ &, 301 \\
\hline
\end{tabular}

Table 11 shows the results for the pearson correlation analysis which reveals the relationship between the students' attitude toward physical education and sports class and academic selfefficacy scores. Lastly, the results showed that there was not a significant relationship between the attitude toward physical education and sports class and academic self-efficacy.

\section{Discussion and Conclusion}

Sample group of the study included 174 female (71.00\%); 71 male (29\%); 26 14-year-old (10.6\%); 145 15-year-old (59.2\%); 59 16-year-old (24.1\%) and 15 17-year-old (6.1\%) students. 137 of the students (55.9\%) participated in school sports; while 108 of them $(44.1 \%)$ did not participate in school sports. On the other hand, 26 of the students (10.6\%) participated in licensed sports; while 219 of them $(89.4 \%)$ did not participate in licensed sports. Similar studies with vocational high school of health students showed the sample numbers between 237, 4678 and 8796. These numbers indicate that the present study requires a more crowded sample group. Additionally, another important result of the table is the fact that rate of participating in licensed sports is low (n:26; 10.6\%).

Descriptive statistics results of the vocational high school of health students' attitude toward physical education and sports class scores and academic self-efficacy scores reveal that the mean of the students' attitude scores is 124.16; while the mean of their academic self-efficacy scores is 17.00. While these scores are close to average values, they can be considered slightly above average. In the light of this information, we can say that the sample group is suitable for the variables.

When the students' attitude toward physical education and sports class scores were compared according to their age group, the results did not reveal any statistical difference ( $p>0.05)$. Contrary to the results of the present study, Akandere et al., (2010) and Kangalgil et al. (2006) found that attitude toward physical education and sports class scores and gender variable differed in support of males $(\mathrm{p}<0.05)$. A similar result to the present study was found in the study of Güllü et al. (2016). Moreover, Luke and Sinclair (1991) female and male 
students had similar attitudes toward physical education and sports class. On the other hand, Moral-Garcia et al. (2018) found that results were in support of the female students. Fox et al. (2010) stated that female high school students thought of sports as a lesson; therefore academic concerns may influence their attitude. In the light of these results, we can say that local and cultural factors influence the attitude toward physical education and sports class. Although there have been great developments lately, general positive results for the males can stem from the fact that it is a male-dominant country where local and regional characteristics are still present.

The students' attitude scores differed significantly in support of the ones who participate in sports when compared according to participation in school or licensed sports $(\mathrm{p}<0.05)$. Akandere et al. (2010) and Kangalgil et al. (2006) found similar results in support of the present study for both participating in school sports and licensed sports. The reason for this result may stem from the fact that doing sports enables one to feel energetic, socially active and help build new status in a social structure.

The findings revealed that academic self-efficacy scores of the vocational high school of health students differed according to gender $(\mathrm{p}<0.05)$ in support of the female students. While Kim and Hong (2019) and Keskin et al. (2016) found different results in support of the male students; Dishman et al. (2008) claimed that self-efficacy of females could stem from cognitive and social basis and that it could be improved. When social influences which pose as obstacles are decreased, self-efficacy in females can increase. On the other hand, Eroğlu et al. (2017) stated in their study that there was not a significant difference between self-efficacy and gender. This situation may be explained through the fact that females feel the need to succeed because of social factors and that there is a natural environment for competition as female students outnumber the males.

Another result revealed that academic self-efficacy scores of vocational high school of health students did not differ according to their age group and whether or not they participated in school or licensed sports ( $p>0.05)$. While the number of studies was limited on this subject, Chase (2001) claimed that increasing self-efficacy would also increase participation in sports. Therefore, although the results of the present study remain unchanged, future extensive studies may help uncover this context.

Last result of the study was that there was no significant relationship between the attitude scores of the students toward physical education and sports class and their self-efficacy scores ( $p>0.05$ ). Keskin, Öncü and Küçük (2016) found a positively significant relationship between attitude and self-efficacy. Moritz et al. (2000) who studied the variance between self-efficacy and performance analyzed 45 studies and found the correlation between self-efficacy and sports performance as .38. These results may indicate that there is a strong connection between attitude toward physical education and sports class and academic self-efficacy.

As a result, the present study reached the following conclusions;

- Participating in licensed sports among vocational high school of health students was low, 
- Vocational high school of health students had a positive attitude toward physical education and sports class,

- Participating in school or licensed sports increased the attitude toward physical education and sports class significantly $(\mathrm{p}<0.05)$,

- Female students had higher means in academic self-efficacy scores.

The study can suggest vocational high school of health students to participate in licensed sports, a more extensive study on the subject and guidance for male students which will motivate them to increase their academic self-efficacy. 


\section{REFERENCES}

Akandere, M., Özyalvaç, N. T., \& Duman, S. (2010). The Attitudes of The Students in Secondary Education to Physical Education Lesson and The Investigation of Their Success Motivations (Konya Anatolian High School Sample). Selçuk University Journal of Social Sciences Institute, (24), 1-10.

Akbay, S. E. (2009). Academic Procrastination of University Students According to Gender: The Role of Academic Motivation, Akademic Self-Efficacy and Academic Attributional Style. Unpublished Master's Thesis, Mersin University Institute of Social Sciences, Mersin.

Akcan, F., Bulgu, N. (2012). Socialization into Sport Process: An Application to High School Students. Journal of Sport Sciences, 23(4), 195-206.

Aksu, N. (2015). The Research of The Relationship Between the Academic Self-Competence, Social Relation Elements and Crime Tendency of The High School Students. Master Thesis, Zirve University, Institute of Social Sciences, Gaziantep.

Aktaş, H. (2017). The Relationship Between Academic Motivation and Academic SelfEfficacy: An Empirical Research on the Students of the Faculty of Teology. Journal of Human and Social Sciences Researches Volume / Vol: 6, Issue / Issue: 3, 2017 Page: 13761398.

Bandura, A. (1977). Self-Efficacy: Toward a unifyingtheory of behavioralchange. PsychologyReview, 84, 191- 215.

Chase, M. A. (2001). Children's self-efficacy, motivational intentions, and attributions in physical education and sport. Research Quarterly for exercise and Sport, 72(1), 47-54.

Dishman, R. K., Saunders, R. P., Motl, R. W., Dowda, M., \& Pate, R. R. (2008). Self-efficacy moderates the relation between declines in physical activity and perceived social support in high school girls. Journal of pediatric psychology, 34(4), 441-451.

Eggen, P. ve Kauchak, D. (1999). EducationalPsychology. (4th ed.). New Jersey: PrinticeHall, Inc. Ferrari, J. R. (1989). Reliability of academicanddispositionalmeasures of procrastination. PsychologicalReports, 64, 1057-1058

Eroğlu, O., Yıldırım, Y., \& Şahan, H. (2017). The Students at the Faculty of Sport Sciences Academic Self-Efficacy and Academic Examination of the Relationship Between Levels of Motivation: Example of Akdeniz Universit. Journal of Sports Sciences Turkey, 1(1), 38-47.

Fox, C. K., Barr-Anderson, D., Neumark-Sztainer, D., \& Wall, M. (2010). Physical activity and sports team participation: Associations with academic outcomes in middle school and high school students. Journal of school health, 80(1), 31-37. 
Güllü, M., Cengiz, Ş. Ş., Öztaşyonar, Y., \& Kaplan, B. (2016). Study Of Behaviors Of Secondary School Students Towards The Physical Education Lesson In Terms Of Some Variances (Case Of Şanliurfa). Gaziantep University Journal of Sport Sciences, 1(2), 49-61.

Güllü M. ve Güçlü M. (2009). Devolopıng of Attıtude Scale Of Physical Education Lesson For Secondary Education Students. Nigde University Journal of Physical Education and Sports Sciences, 3 (2), 5-22.

Hamad Amin, B.M. (2018) Examination of academic self-efficacy and quality of life of university students according to physical activities. (The case of Van). Master Thesis. Van Yüzüncü Y1l University, Institute of Educational Sciences, Van.

Janssen, I., LeBlanc, A. G. (2010). Systematic review of the health benefits of physical activity and fitness in school-aged children and youth. International journal of behavioral nutrition and physical activity, 7(1), 40.

Jerusalem, M., Schwarzer, R. (1981). Fragebogen zur Erfassung von "Selbstwirksamkeit. Skalen zur Befindlichkeit und Persoenlichkeit In R. Schwarzer (Hrsg.). (Forschungsbericht No. 5). Berlin: Freie Universitaet, Institut fuer Psychologie.

Kangalgil, M., Hünük, D., \& Demirhan, G. (2006). Comparison of Elementary School, High School and University Students' Attitudes Toward Physical Education and Sport. Journal of Sport Sciences, 17(2), 48-57.

Karakaş, G., Yaman, C. (2014). The Role of Family in Motivating The Children With Disabilities To Do Sport. Procedia-Social and Behavioral Sciences, 152, 426-429.

Karasar, N. (2016). Scientific Research Methods: Concepts, Principles and Techniques. (31st Edition). Ankara: Nobel Publication Distribution.

Keskin, N., Öncü, E., \& Küçük, K. S. (2016). Attıtudes and Self-Effıcacy of Middle School Students Toward Physical Education Classes. Journal of Physical Education and Sport Sciences, 14(1), 93-107.

Kim, H. J., \& Hong, S. M. (2019). The Effects of Grit and Academic Self-Efficacy on Major Satisfaction among Students in Health-Related College Majors. Medico-Legal Update, 19(1), 496-500.

Luke, M. D., \& Sinclair, G. D. (1991). Gender differences in adolescents' attitudes toward school physical education. Journal of Teaching in physical Education, 11(1), 31-46.

Luszczynska, A., Gutiérrez-Doña, B., \& Schwarzer, R. (2005). General self-efficacy in various domains of human functioning: Evidence from five countries. International journal of Psychology, 40(2), 80-89.

Macgregor, A. P., Borghese, M. M., \& Janssen, I. (2019). Is replacing time spent in one type of physical activity with another associated with health in children?. Applied Physiology, Nutrition, and Metabolism, (ja). 
Moral-García, J. E., Ruiz-Ariza, A., Grao-Cruces, A., Manuel, J., \& Martínez-López, E. J. (2018). Satisfaction of Spanish high school students with physical education: gender, age, physical activity level and body type. South African Journal for Research in Sport, Physical Education and Recreation, 40(1), 71-84.

Moritz, S. E., Feltz, D. L., Fahrbach, K. R., \& Mack, D. E. (2000). The relation of selfefficacy measures to sport performance: A meta-analytic review. Research quarterly for exercise and sport, 71(3), 280-294.

Physical Activity Guidelines Advisory Committee. (2008). Physical activity guidelines advisory committee report, 2008. Washington, DC: US Department of Health and Human Services, 2008, A1-H14.

Schunk, D.H. (2009). Learning Theories, an educational perspective (Trans.Ed.Muzaffer Sahin), Nobel Publication Distribution, Ankara: 137.

Strong, W. B., Malina, R. M., Blimkie, C. J., Daniels, S. R., Dishman, R. K., Gutin, B., ... \& Rowland, T. (2005). Evidence based physical activity for school-age youth. The Journal of pediatrics, 146(6), 732-737.

Yılmaz, M., Gürçay, D., \& Ekici, G. (2007). Adaptatıon of The Academıc Self-Efficacy Scale To Turkısh. Hacettepe Unıversity Journal of Education, 33(33), 253-259.

Yorulmaz, M. (2019). Academic Self-Efficacy In Students: Department of Health Management. Business \& Management Studies: An International Journal, 7(1), 172-189.

Zhang, Y., Dong, S., Fang, W., Chai, X., Mei, J., \& Fan, X. (2018). Self-efficacy for selfregulation and fear of failure as mediators between self-esteem and academic procrastination among undergraduates in health professions. Advances in Health Sciences Education, 23(4), 817-830.

Zimmerman, B. J. (1995). Self-efficacy and educational development. In A. Bandura (Ed.), Selfefficacy in changing societies. s. 202-231. New York: Cambridge University Press. 